\title{
Die relatiewe belangrikheid van keuringskriteria soos waargeneem vanuit die oogpunt van verbruikersbankbestuurders
}

\author{
P.L.S. Ackemann
}

Skool vir Bedryfsleiding, Universiteit van Suid-Afrika, Pretoria

W.P.J. van Rensburg

Departement Bedryfsekonomie, Universiteit van Suid-Afrika, Pretoria

\begin{abstract}
The relative importance of evaluation criteria as observed by bank managers in consumer banking. This study has the following objectives: (i) To determine the relative importance of various evaluation criteria (as observed by bank managers) in considering the granting of credit to individuals in consumer banking; and (ii) to compare the relative importance of evaluation criteria (as observed by bank managers) with regard to the various race groups (coloureds, Indians, whites, and blacks). The sample consists of $\mathbf{5 1 0}$ managers from the consumer division of general and commercial banks. It was found that significant differences exist regarding the relative importance of the evaluation criteria (according to the perception of bank managers) with respect to the various race groups.

S. Afr. J. Bus. Mgmt. 1985, 16: $138-145$

In hierdie ondersoek word gepoog om: (i) Die relatiewe belangrikheid van verskeie keuringskriteria (soos waargeneem vanuit die oogpunt van bankbestuurders) in verbruikersbankwese te bepaal; en (ii) die relatiewe belangrikheid van die keuringskriteria (soos waargeneem vanuit die oogpunt van bankbestuurders) by die verskillende rassegroepe (kleurlinge, Indiërs, blankes en swartes) te vergelyk. Die steekproef bestaan uit 510 bestuurders in die verbruikersafdeling van algemene- en handelsbanke. Daar is bevind dat beduidende verskille bestaan wat betref die relatiewe belangrikheid van keuringskriteria (volgens bankbestuurders se persepsie) rakende die onderskeie rassegroepe.

S.Afr. Tydskr. Bedryfsl. 1985, 16: 138-145
\end{abstract}

\section{P.L.S. Ackermann}

Skool vir Bedryfsleiding, Universiteit van Suid-Afrika,

Posbus 392, Pretoria, 0001 Republiek van Suid-Afrika

W.P.J. van Rensburg

Departement Bedryfsekonomie, Universiteit van Suid-Afrika,

Posbus 392, Pretoria, 0001 Republiek van Suid-Afrika

*Aan wie korrespondensie gerig moet word

Aanvaar April 1985

\section{Inleiding}

Die voorspelling van kredietrisiko's ter bekamping van onverhaalbare skulde het gedurende die afgelope aantal jare toenemend belangrik geword. Verskeie ondersoeke, byvoorbeeld dié deur Pinches \& Mingo (1973); Sexton (1977); Tabor \& Bowers (1977); Winginton (1980) en Van Rensburg (1983) het as uitgangspunt gehad om kredietrisiko's reeds in die aansoekstadium te probeer voorspel. Die soektog na geskikte voorspellers van kredietrisiko's duur steeds voort, hoofsaaklik omdat die verklaarde proporsie variansie van kredietrisiko in baie van die ondersoeke te laag is om die voorspellingsmodelle in die praktyk sinvol te kan gebruik.

In die Republiek van Suid-Afrika styg die lewenspeil van veral die kleurlinge, Indiërs en swartes vinnig. Die verwagte groter vraag na finansiële dienste deur laasgenoemde drie groepe, sal veral die bankinstellings binne die finansiële diensindustrie onder toenemende druk plaas. Met die verwagte toetrede van meer bevolkingsgroepe tot die gebied van kredietverlening deur bankinstellings, bouverenigings en ander finansiële instellings, behoort die kredietevalueringsproses of keuring soos dit ook bekend staan, ook meer aandag te geniet. Verbruikersbankbestuurders was tradisioneel met die blanke as verbruiker bekend, maar die vraag ontstaan nou of die evaluering van kredietaansoeke vir kleurlinge, Indiërs en swartes volgens dieselfde norme beoordeel kan word, al dan nie. Bankbestuurders se persepsie van die kredietevalueringskriteria met betrekking tot ander groepe in die bevolkingsamestelling, sal moontlik antwoorde kan verskaf wat in die toekoms as riglyne kan dien. Persepsie is 'n proses waartydens die bestuurder as individu verskeie stimuli evalueer en interpreteer. Dunham (1984:24) is van mening dat individue se persepsie van sekere stimuli in hul omgewing, 'n noue verband met hul gedragspatroon en optrede het.

Kredietverlening gee aanleiding tot die aanvaarding van goeie- en swak kredietrisiko's. Swak kredietrisiko's gee weer aanleiding tot die afskrywing van onverhaalbare skulde. Bankbestuurders is dit eens dat vandag se swak kredietrisiko's die oorgrote persentasie van môre se afskrywings as onverhaalbare skuld uitmaak. Bankinstellings in die Republiek van Suid-Afrika se werklike afskrywings word nie gepubliseer nie, maar ' $n$ algemeen aanvaarde syfer van $0,5 \%$ in die geval van afbetalingsverkooptransaksies (huurkope) en huurtransaksies word telkens in bankkringe genoem. As hierdie norm vir berekeningsdoeleindes aanvaar word, word gevind dat in 1973, R4,16 miljoen afgeskryf is teenoor R78,79 miljoen in 1984, indien die Kwartaalverslag van die Suid-Afrikaanse Reserwebank se batesyfers vir bankinstellings op 31 Desember 1984, as basis geneem word. Kredietevaluering is die taak van 
hoofsaaklik verbruikersbankbestuurders. Die kredietevalueringsproses kan in verskillende vorms voorkom. Sommige bankinstellings byvoorbeeld, verkies om hul kredietevaluering deur 'n paneel van senior amptenare te laat afhandel terwyl ander die bestuurder en/of kredietbestuurder toelaat om binne sekere bedraglimiete aansoeke om krediet op hul eie te evalueer. Watter beleid ookal gevolg word, is dit dié proses waartydens die aansoeker om krediet se aansoekvorm noukeurig aan die hand van sekere kriteria en voorgeskrewe riglyne van die betrokke bankinstelling, ontleed word en 'n besluit om die krediet toe te staan of van die hand te wys, geneem word. Tydens hierdie belangrike proses word goeieof swak risiko's dus aanvaar of nie aanvaar nie. Dit is die eerste skakel in die kredietverleningsketting.

\section{Doel en omvang van die ondersoek}

Die doel van die ondersoek is om by die oorweging van kredietverlening aan 'n verbruiker die relatiewe belangrikheid van verskeie keuringskriteria te bepaal, soos waargeneem vanuit die oogpunt van bankbestuurders. Die ondersoek is beperk tot handels- en algemene banke omrede hulle die grootste voorsieners van verbruikerskrediet in die vorm van afbetalingsverkooptransaksies en huurtransaksies is. (Vergelyk die kumulatiewe groei in bates van handels- en algemene banke met die kumulatiewe groei in afbetalingsverkooptransaksies en huurtransaksies soos weergegee in Tabelle 1 en 2.)

Die insluiting van Indiërs, kleurlinge, blankes en swartes as grootste deel van die Suid-Afrikaanse bevolkingsamestelling, is gedoen om die resultate en moontlike afleidings uit die ondersoek so omvattend en verteenwoordigend as moontlik te maak van die totale bevolkingsamestelling. Veral in die lig van die snelgroeiende koopkrag en welvarendheid van die Indiërs, kleurlinge en swartes in die Suid-Afrikaanse gemeenskap, is dit vanselfsprekend dat dié groep ook by 'n ondersoek van hierdie aard ingesluit behoort te word.

\section{Literatuuroorsig}

Die Tweede Wêreldoorlog $(1939-1945)$ is gekenmerk deur

Tabel 1 Totale bates en kumulatiewe groei in bates van handels- en algemene banke in die finansiële diensindustrie in die Republiek van SuidAfrika vanaf 31 Desember 1973 tot 31 Desember 1984 ( $R$, miljoen)

\begin{tabular}{|c|c|c|c|c|c|c|}
\hline $\begin{array}{l}\text { Jaar } \\
\text { eindigend }\end{array}$ & $\begin{array}{c}\text { Handels- } \\
\text { banke }\end{array}$ & $\begin{array}{l}\text { Kumulatiewe } \\
\text { groei: } \\
\text { Handels- } \\
\text { banke: } 1973 \\
=100\end{array}$ & $\begin{array}{l}\text { Algemene } \\
\text { banke }\end{array}$ & $\begin{array}{l}\text { Kumulatiewe } \\
\text { groei: } \\
\text { Algemene } \\
\text { banke: } 1973 \\
=100\end{array}$ & Totaal & $\begin{array}{l}\text { Kumulatiewe } \\
\text { groei: Totaal } \\
\text { van handels- } \\
\text { en algemene } \\
\text { banke: } 1973 \\
=100\end{array}$ \\
\hline 1973 & 5740 & 100 & 2480 & 100 & 8220 & 100 \\
\hline 1974 & 6823 & 118,9 & 2771 & 111,7 & 9594 & 116,7 \\
\hline 1975 & 8130 & 141,6 & 3461 & 139,6 & 11591 & 141,0 \\
\hline 1976 & 9119 & $158, y$ & 3897 & 157,1 & 13016 & 158,3 \\
\hline 1977 & 9795 & 170,6 & 4094 & 165,1 & 13889 & 169,0 \\
\hline 1978 & 11139 & 194,1 & 4770 & 192,3 & 15909 & 193,5 \\
\hline 1979 & 13368 & 232,9 & 5518 & 222,5 & 18886 & 229,8 \\
\hline 1980 & 15832 & 275,8 & 8000 & 322,6 & 23832 & 289,9 \\
\hline 1981 & 19487 & 339,5 & 11616 & 468,4 & 31103 & 378,4 \\
\hline 1982 & 26092 & 454,6 & 10704 & 431,6 & 36796 & 447,6 \\
\hline 1983 & 30376 & 529,2 & 12561 & 506,5 & 42937 & 522,3 \\
\hline 1984 & 39767 & 692,8 & 15494 & 624,8 & 55261 & 672,3 \\
\hline
\end{tabular}

(Saamgestel uit: Suid-Afrikaanse Reserwebank: Kwartaalverslae Maart 1980-Maart 1985)

Tabel 2 Totale bates in die vorm van afbetalingsverkooptransaksies en huurtransaksies van handelsbanke en algemene banke in die finansiële diensindustrie in die Republiek van Suid-Afrika vanaf 31 Desember 1973 tot 31 Desember 1984 ( $R$, miljoen)

\begin{tabular}{|c|c|c|c|c|c|c|}
\hline $\begin{array}{l}\text { Jaar } \\
\text { eindigend }\end{array}$ & $\begin{array}{l}\text { Handels- } \\
\text { bank }\end{array}$ & $\begin{array}{l}\text { Kumulatiewe } \\
\text { groei (jaar } \\
1973 \text { as } 100 \\
\text { geneem) }\end{array}$ & $\begin{array}{l}\text { Algemene } \\
\text { bank }\end{array}$ & $\begin{array}{l}\text { Kumulatiewe } \\
\text { groei (jaar } \\
1973 \text { as } 100 \\
\text { geneem) }\end{array}$ & Totaal & $\begin{array}{l}\text { Kumulatiewe } \\
\text { groei (jaar } \\
1973 \text { as } 100 \\
\text { geneem }\end{array}$ \\
\hline 1973 & 69 & 100 & 763 & 100 & 832 & 100 \\
\hline 1974 & 138 & 200,0 & 793 & 103,9 & 931 & 111,9 \\
\hline 1975 & 231 & 334,8 & 1143 & 149,8 & 1374 & 165,1 \\
\hline 1976 & 252 & 365,2 & 1444 & 189,2 & 1696 & 203,8 \\
\hline 1977 & 289 & 418,8 & 1557 & 204,1 & 1848 & 204,1 \\
\hline 1978 & 415 & 601,4 & 2120 & 277,9 & 2535 & 304,7 \\
\hline 1979 & 557 & 897,2 & 2780 & 364,4 & 3337 & 401,1 \\
\hline 1980 & 682 & 988,4 & 4348 & 569,9 & 5030 & 604,6 \\
\hline 1981 & 1145 & 1659,4 & 6491 & 850,7 & 7637 & 917,8 \\
\hline 1982 & 2989 & 4331,9 & 6684 & 876,0 & 9673 & 1161,6 \\
\hline 1983 & 3972 & 5756,5 & 8067 & 1057,3 & 12039 & 1446,9 \\
\hline 1984 & 5743 & 8323,2 & 10034 & 1315,1 & 15777 & 1896,3 \\
\hline
\end{tabular}


'n skerp daling in verbnuikerskrediet as gevolg van die skaarste aan verbruikersgoedere gedurende die oorlogsjare. $\mathrm{Na}$ die oorlog het aktiwiteite weer sterk begin toeneem en verdubbel tot rekordvlakke. Verbruikerskrediet het ontwikkel in 'n leefwyse, iets wat deel geword het van bykans elke huishouding - ' $n$ algemeen aanvaarde manier om veral duursame verbruikersartikels te bekom. Veral paaiementsfinansiering (afbetalingsverkooptransaksies en huurtransaksies) het by verbruikers in gewildheid toegeneem. In die Republiek van Suid-Afrika was die groei in laasgenoemde twee soorte verbruikerskrediet volgens die Kwartaalverslag van die SuidAfrikaanse Reserwebank, Maart 1985, gedurende die afgelope dekade bykans $1800 \%$ (Tabel 2).

\section{Kriteria by kredietevaluering aanwesig}

Beckman \& Bartels (1955) was reeds in 1924 (1ste uitgawe) van mening dat kredietevaluering rondom die sogenaamde vier C's sentreer, naamlik 'character, capacity, capital and collateral'. Sinkey (1983:39), deel steeds hierdie mening, maar met die toevoeging van 'n vyfde $C$, naamlik 'conditions'. Die toevoeging van ' $n$ vyfde $C$ word veral deur kredietbestuurders uit die finansiële sektore van die ekonomie as 'n noodsaaklikheid beskou. Cole (1982:301) stel dit dat slegs vrae rakende die historiese agtergrond van die kliënt van belang is. Tweedens behoort slegs vrae wat op voorspellingsmoontlikhede dui aan die kliënt gestel te word, naamlik wat die kliënt se huidige situasie is. Die interpretasie en uiteindelike besluitneming in terme van die voorgelegde inligting is ' $n$ moeilike taak. Cole se standpunt met betrekking tot die probleem van fisiese besluitneming word soos volg gestel (p.301): 'Making these decisions is the single most important credit activity; all other activities of the credit department are contributory to this function'.

Die volgende vrae in verband met die kliënt se kredietwaardigheid is volgens Cole van kernbelang:

- Besonderhede van vorige betaalrekord(s) (historiese agtergrond);

- inkomste (voorspellingskriterium);

- werkgewer en beroep (voorspellingskriterium);

- tydperk woonagtig en plek woonagtig (historiese agtergrond);

- huwelikstatus (historiese agtergrond);

- ouderdom (historiese agtergrond);

- kredietverwysings (historiese agtergrond);

- reserwes, bates (voorspellingskriterium);

- surplus batewaarde in artikel (voorspellingskriterium); en

- sekuriteit (voorspellingskriterium).

Sedert die baanbrekerswerk deur Beckman \& Bartels (1955) tot die meer resente benaderings van Cole (1982) en Sinkey (1983) het verskeie ander navorsers oor die evalueringsproses navorsing gedoen, waaronder Boggess (1967); Wantland (1977); Eisenbeis (1980); Zimmer (1981) en Van Rensburg (1983) die belangrikste bydraes gelewer het.

Die probleem waarmee Boggess (1967) te kampe gehad het, het primêr te doen gehad met die tradisionele kredietevaluering teenoor die gebruik van rekenaars vir kredietevaluering en of laasgenoemde die kredietverleningspatroon sou beinvloed al dan nie. Boggess was van mening dat 'n liberale kredietbeleid aanleiding kon gee tot 'n vermindering van winste weens 'n styging in onverhaalbare skuld, terwyl ' $n$ konserwatiewe beleid ook winste nadelig kan beïnvloed weens ' $n$ daling in omset. Die gebruik van gevorderde statistiese tegnieke en rekenaars in die verlening van verbruikerskrediet, behoort afskrywings in die vorm van onverhaalbare skulde te verminder en te sorg dat goeie kredietrekenings behoue bly. 'n Balans tussen 'n liberale en konserwatiewe evaluering is nodig. Boggess beveel ' $n$ samestelling van ' $n$ rekenaarondersteunde prosedure aan om die meriete van kredietaansoekers met behulp van ' $n$ ontleding van kliënte se persoonlike eienskappe te bepaal. 'n 'Credit-scoring'-metode vir optimale keuring van swak risiko's word voorgestel. Deur die toepassing van 'n statistiese tegniek, soos byvoorbeeld meervoudige diskriminantontleding, word die relatiewe belangrikheid van elke kriterium bepaal. 'n Kredietkeuringsvergelyking bekend as 'n 'credit-scoring model' word saamgestel. Gewigte word met behulp van dié vergelyking bereken. Die metode van gewigtetoekenning aan verskillende keuringskriteria deur gebruikmaking van meervoudige regressie-ontleding of meervoudige diskriminantontleding het sedert Boggess se ondersoek in 1967 baie in gewildheid toegeneem. Verskeie navorsers, byvoorbeeld Stanhouse \& Sherman (1979), Rothenberg (1980), Grablowsky (1981) en Van Rensburg (1983) het onder meer ondersoeke gedoen waarin van soortgelyke statistiese tegnieke gebruik gemaak is. Baie van hierdie ondersoeke is gekritiseer omdat die proporsie variansie van kredietrisiko verklaar baie laag was en die modelle dus nie 'n groot bydrae kon lewer om die kredietevalueringstaak van bestuurders te vergemaklik nie.

Dickson (1981) het ondersoek ingestel na die invloed en houdings jeens die begrip risiko in finansiële besluitnemings wat die voorspelling van risiko ingesluit het. Van die vroeëre navorsers op dié terrein was, onder andere, Grayson (1960) en Spetzler (1968), terwyl Handa (1977) en Karmarker (1978) van die meer resente navorsingstukke die lig laat sien het. Al die ondersoeke was egter gerig op spekulatiewe risikobesluitneming - dit is besluite wat byvoorbeeld die moontlikheid van of ' $n$ wins of ' $n$ verlies ingehou het.

Die mening word gehuldig dat kredietrisiko en kredietrisikovoorspellings nie eensydig spekulatief van aard kan wees nie en daarom kan besluitnemings met betrekking tot die aanvaarding, al dan nie, ook nie as spekulatiewe besluitneming beskou word nie. 'n Bestuurder se doel wanneer hy 'n aansoek om krediet evalueer en dit aanvaar, is om ' $n$ wins uit die transaksie te realiseer en nie om 'n verlies te toon nie. Kredietbesluite is dus positiewe besluite. Geen ondersoeke kon gevind word waarin die persepsie van bestuurders bepaal is jeens risiko in besluitnemings wat dui op ' $n$ verliesvooruitsig as sulks nie. Daar was wel besluitnemings ter voorkoming van verliese en dit is besluite om winste te beskerm of te verstewig.

Tabor \& Bowers (1977) het in hul ondersoek probeer om die veranderlikes wat gebruik word in die kredietevaluering van lae-inkomste-verbruikers te identifiseer. Ten einde krediet te kan bekom moet ' $n$ verbruiker oor sekere eienskappe beskik wat die lener sal oortuig dat die aansoeker sy skuld sal betaal. In die ondersoek van Tabor \& Bowers is 800 rekenings van lae-inkomste-verbruikers met behulp van meervoudige regressie-ontleding gebruik om 'n kredietevalueringsmodel saam te stel. Die model het geblyk ongeskik te wees om goeie- en swak risiko's te identifiseer. Onafhanklike veranderlikes wat normaalweg by die hoër inkomstegroep in die vergelyking ingesluit is, soos byvoorbeeld besit van ' $n$ telefoon, besit van ' $n$ bankrekening en tydperk werksaam by huidige werkgewer, is nie geselekteer in die voorspellingsmodel van lae-inkomstegroepe nie. Andersom is ander onafhanklike veranderlikes soos salarisaftrekkings, ouderdom, huwelikstatus en aanwesigheid van 'n verband geselekteer, wat nie by hoërinkomstegroepe die geval was nie.

Die ondersoek van Tabor $\&$ Bowers het beslis die vraag of hoë- en lae-inkomstegroepe oor dieselfde kam geskeer moet word wanneer dit by kredietevaluering en die gebruikmaking 
van kredietevalueringsmodelle kom, uitgelig. Tabor \& Bowers (1977:51) stel, heeltemal tereg: 'early recognition and treatment, perhaps in the form of credit counselling or consumer education might forestal progression to charge-offs'.

\section{Probleemstellings en hipoteses}

Die volgende twee probleme kan geformuleer word:

- Wat is die relatiewe belangrikheid van verskeie keuringskriteria (soos waargeneem vanuit die oogpunt van bankbestuurders) in verbruikersbankwese?

- Hoe vergelyk die relatiewe belangrikheid van die keuringskriteria (soos waargeneem vanuit die oogpunt van bankbestuurders) by die verskillende rassegroepe?

Twee hipoteses, wat verband hou met die voorafgaande twee probleme, sal ondersoek word:

\section{Hipotese 1}

$\mathrm{H}_{0}$ (Nulhipotese): Daar is geen verskil wat betref die relatiewe belangrikheid van die keuringskriteria (soos waargeneem vanuit die oogpunt van bankbestuurders) met betrekking tot die verskillende rassegroepe nie.

$\mathrm{H}_{1}$ (alternatiewe hipotese): Daar is 'n verskil wat betref die relatiewe belangrikheid van die keuringskriteria soos waargeneem vanuit die oogpunt van bankbestuurders) met betrekking tot die verskillende rassegroepe.

\section{Hipotese 2}

$\mathrm{H}_{0}$ : Daar is geen korrelasie tussen die relatiewe belangrikheid wat bankbestuurders aan die keuringskriteria met betrekking tot die verskillende rassegroepe heg nie.

$\mathrm{H}_{1}$ : Laar is ' $\mathrm{n}$ korrelasie tussen die relatiewe belangrikheid wat bankbestuurders aan die keuringskriteria met betrekking tot die verskillende rassegroepe heg.

\section{Rasionaal vir hipoteses 1 en 2}

Bestuurders se omstandighede verskil in vele opsigte van mekaar, byvoorbeeld ouderdom, ondervinding, verskille in filosofie van werkgewers, verskille in aansoekvorm-uitleg, tydsbenutting, deelname in bestuursbesluite, verdienstepakkette, opvoedkundige kwalifikasies, geografiese gebiede en benaderings tot kredietrisiko's. Dit het daarom nodig geword om die persepsie van die deursnee bestuurder in sy besluitnemingsaksie met betrekking tot kredietevaluering in die Republiek van Suid-Afrika, na te vors.

Aanvullend tot die voorafgaande stelling het Tabor \& Bowers (1977) en Sexton, jr. (1977) in hul ondersoeke met betrekking tot die identifisering van veranderlikes wat eie aan lae-inkomste-verbruikers is, nie noemenswaardige verskille vergeleke met hoë-inkomste-verbruikers gevind nie. In die Suid-Afrikaanse konteks is die kleurlinge, Indiërs en swartes algemeen bekend as die laer-inkomste-verbruikers, terwyl die blankes die hoër-inkomstegroep verteenwoordig. Die keuringskriteria aan bankbestuurders voorgelê by die evaluering van kredietaansoeke deur blankes, kleurlinge, swartes en Indiërs is identies. Die vraag ontstaan nou of bankbestuurders genoemde aansoeke in die praktyk ook identies evalueer. Die voorgaande twee hipoteses hou verband met hierdie vraag.

\section{Navorsingsontwerp en -ontleding}

Die steekproef bestaan uit 510 bestuurders in die verbruikersafdeling van die algemene- en handelsbanke. Die geografiese verspreiding van die bestuurders word in Tabel 3 aangetoon. Die bestuurders wat aan die steekproef deelgeneem het, was almal vir ten minste een jaar 'n bankbestuurder met dieselfde of langer ondervinding van kredietevaluering. Die persentasie
Tabel 3 Geografiese verspreiding van bestuurderssteekproef oor die Republiek van Suid-Afrika

\begin{tabular}{lcc}
\hline Gebied & $\begin{array}{c}\text { Aantal } \\
\text { bestuurders }\end{array}$ & Persentasie \\
\hline Pretoria/Johannesburg & 158 & 30,98 \\
Vereeniging en Vaaldriehoek & 31 & 6,08 \\
Durban/Pietermaritzburg en & & \\
$\quad$ omliggende gebiede & 36 & 7,06 \\
Kaapstad/Bellville en omgewing & 45 & 8,02 \\
Port Elizabeth en omgewing & 26 & 5,10 \\
Bloemfontein/Welkom & 15 & 2,94 \\
Transvaalse plattelandse gebiede & 112 & 21,96 \\
Natalse plattelandse gebiede & 23 & 4,51 \\
Kaapse plattelandse gebiede & 42 & 8,24 \\
Vrystaatse plattelandse gebiede & 22 & 4,31 \\
Totaal & 510 & 100 \\
\hline
\end{tabular}

bestuurders met min ondervinding van kredietevaluering was egter aansienlik minder in getalle as die bestuurders met jarelange ondervinding. Die gemiddelde tydperk werksaam as bestuurders en gemiddelde tydperk van ondervinding van kredietevaluering, word tesame met sekere persoonlike besonderhede, in Tabel 4 verskaf.

Die vraelys bestaan uit 22 keuringskriteria. Ten einde die inhoudsgeldigheid van die vraelys te verhoog, is met die hulp van die bankbestuur gepoog om die evalueringskriteria verteenwoordigend te maak van al daardie kriteria wat normaalweg by die evalueringsproses aanwesig is. Die keuringskriteria in die vraelys ingesluit, is die volgende: Bruto inkomste; besit van lewens en/of uitkeerversekering; huwelikstatus; aantal afhanklikes, tydperk woonagtig by huidige adres; beroep; ouderdom van artikel gefinansier; afbetalingstussenposes; binne- en buiteverwysings; besit van bankrekening; bestaande of nuwe kliënt; besit van vaste eiendom; besit van telefoon by woonadres; ouderdom van aansoeker; afbetalingstermyn; vonnisse teen kredietrekord; geslag; tydperk werksaam by

Tabel 4 Persoonlike besonderhede van bankbestuurders wat by bestuurderssteekproef ingesluit is

\begin{tabular}{|c|c|c|c|}
\hline $\begin{array}{l}\text { Item } \\
\text { nr. }\end{array}$ & $\begin{array}{l}\text { Persoonlike besonderhede } \\
\text { van bestuurders }\end{array}$ & Aantal & $\begin{array}{l}\text { Persentasie/ } \\
\text { Standaard- } \\
\text { afwyking }\end{array}$ \\
\hline 1 & Stedelike gebied werksaam & 311 & 60,98 \\
\hline 2 & Plattelandse gebied werksaam & 199 & 39,02 \\
\hline 3 & Huistaal Afrikaans & 432 & 84,71 \\
\hline 4 & Huistaal Engels & 78 & 15,29 \\
\hline 5 & $\begin{array}{l}\text { Hoogste opvoedkundige } \\
\text { kwalifikasies }\end{array}$ & & \\
\hline 5.1 & Standerd agt & 15 & 2,94 \\
\hline 5.2 & Standerd tien & 396 & 77,65 \\
\hline 5.3 & Diploma kursus & 59 & 11,57 \\
\hline 5.4 & B-graad & 34 & 6,67 \\
\hline 5.5 & Honneursgraad & 5 & 1,00 \\
\hline 5.6 & M-graad & 1 & 0,17 \\
\hline 6 & $\begin{array}{l}\text { Gemiddetde tydperk as } \\
\text { bestuurder werksaam }\end{array}$ & 6,53 jaar & a 5,8865 \\
\hline 7 & $\begin{array}{l}\text { Gemiddelde tydperk as krediet- } \\
\text { evalueringsamptenaar } \\
\text { werksaam }\end{array}$ & 10,09 jaar & 6,7018 \\
\hline 8 & $\begin{array}{l}\text { Gemiddelde bruto inkomste } \\
\text { per jaar }\end{array}$ & R24 340 & ${ }^{2} \mathrm{R} 1903$ \\
\hline 9 & $\begin{array}{l}\text { Gemiddelde ouderdom van } \\
\text { bestuurders }\end{array}$ & 41,21 jaar & 8,2494 \\
\hline
\end{tabular}

Standaardafwyking 
vorige werkgewer; gebied woonagtig; totale uitgawes; tydperk werksaam by huidige werkgewer; en taal.

Hipotese 1 is met behulp van variansie-ontleding getoets. Indien $F$ statisties beduidend was, is die toepaslike prosedure van Sheffé gebruik om beduidende vergelykings op te spoor. Vir die toetsing van hipotese 2 is daar van Kendall se rangordekorrelasietegniek $(W)$ gebruik gemaak.

\section{Resultate en Interpretasie}

In Tabel 5 word die variansie-ontleding met keuringskriteria ten opsigte van Indiërs, kleurlinge, blankes en swartes weergegee. Dit is duidelik dat daar beduidende verskille op die 0,01-vlak ten opsigte van 20 uit die 22 keuringskriteria met betrekking tot die onderskeie rassegroepe voorgekom het. Slegs in die geval van twee keuringskriteria, naamlik aanwesig-

Tabel 5 Variansie-ontleding met keuringskriteria ten opsigte van verskillende rassegroepe

\begin{tabular}{|c|c|c|c|c|c|c|c|}
\hline $\begin{array}{l}\text { Kriteria } \\
\text { nommer }\end{array}$ & Beskrywing van keuringskriterium & $\begin{array}{l}\text { Soort } \\
\text { variansie }\end{array}$ & $\begin{array}{l}\text { Som van } \\
\text { kwadrate }\end{array}$ & $\begin{array}{c}\text { Graad van } \\
\text { vryheid } \\
(g v)\end{array}$ & $\begin{array}{c}\text { Gemiddelde } \\
\text { kwadrate }\end{array}$ & $F$-waarde & $\begin{array}{c}\text { Betekenisvol } \\
\text { beduidend op } \\
\alpha \text {-vlak }\end{array}$ \\
\hline 1 & Bruto inkomste van kliënt & $\begin{array}{l}\text { Tussen groepe } \\
\text { Binne groepe }\end{array}$ & $\begin{array}{r}39,07 \\
1094,97\end{array}$ & $\begin{array}{r}3 \\
2036\end{array}$ & $\begin{array}{r}13,02 \\
0,54\end{array}$ & 24,11 & 0,01 \\
\hline 2 & Aanwesigheid van lewens- en/of uitkeerversekering & $\begin{array}{l}\text { Tussen groepe } \\
\text { Binne groepe }\end{array}$ & $\begin{array}{r}5,36 \\
3457,80\end{array}$ & $\begin{array}{r}3 \\
2036\end{array}$ & $\begin{array}{l}1,79 \\
1,70\end{array}$ & 1,05 & Onbeduidend \\
\hline 3 & Huwelikstatus & $\begin{array}{l}\text { Tussen groepe } \\
\text { Binne groepe }\end{array}$ & $\begin{array}{r}24,79 \\
3095,70\end{array}$ & $\begin{array}{r}3 \\
2036\end{array}$ & $\begin{array}{l}8,26 \\
1,52\end{array}$ & 5,43 & 0,01 \\
\hline 4 & Aantal afhanklikes & $\begin{array}{l}\text { Tussen groepe } \\
\text { Binne groepe }\end{array}$ & $\begin{array}{r}45,96 \\
3060,00\end{array}$ & $\begin{array}{r}3 \\
2036\end{array}$ & $\begin{array}{r}15,32 \\
1,50\end{array}$ & 10,21 & 0,01 \\
\hline 5 & Tydperk woonagtig by huidige adres & $\begin{array}{l}\text { Tussen groepe } \\
\text { Binne groepe }\end{array}$ & $\begin{array}{r}90,43 \\
1788,06\end{array}$ & $\begin{array}{r}3 \\
2036\end{array}$ & $\begin{array}{r}30,14 \\
0,88\end{array}$ & 34,25 & 0,01 \\
\hline 6 & Beroep & $\begin{array}{l}\text { Tussen groepe } \\
\text { Binne groepe }\end{array}$ & $\begin{array}{r}47,44 \\
1981,86\end{array}$ & $\begin{array}{r}3 \\
2036\end{array}$ & $\begin{array}{r}15,81 \\
0,97\end{array}$ & 16,30 & 0,01 \\
\hline 7 & Ouderdom van artikel & $\begin{array}{l}\text { Tussen groepe } \\
\text { Binne groepe }\end{array}$ & $\begin{array}{r}120,11 \\
1461,66\end{array}$ & $\begin{array}{r}3 \\
2036\end{array}$ & $\begin{array}{r}40,04 \\
0,72\end{array}$ & 55,61 & 0,01 \\
\hline 8 & Afbetalingstussenposes & $\begin{array}{l}\text { Tussen groepe } \\
\text { Binne groepe }\end{array}$ & $\begin{array}{r}164,99 \\
2228,70\end{array}$ & $\begin{array}{r}3 \\
2036\end{array}$ & $\begin{array}{r}55,00 \\
1,09\end{array}$ & 50,46 & 0,01 \\
\hline 9 & Kredietverwysings & $\begin{array}{l}\text { Tussen groepe } \\
\text { Binne groepe }\end{array}$ & $\begin{array}{r}48,20 \\
1601,40\end{array}$ & $\begin{array}{r}3 \\
2036\end{array}$ & $\begin{array}{r}16,07 \\
0,79\end{array}$ & 20,34 & 0,01 \\
\hline 10 & Besit van bankrekening & $\begin{array}{l}\text { Tussen groepe } \\
\text { Binne groepe }\end{array}$ & $\begin{array}{r}38,96 \\
2442,90\end{array}$ & $\begin{array}{r}3 \\
2036\end{array}$ & $\begin{array}{r}12,99 \\
1,20\end{array}$ & 10,83 & 0,01 \\
\hline 11 & Bestaande of nuwe kliënt & $\begin{array}{l}\text { Tussen groepe } \\
\text { Binne groepe. }\end{array}$ & $\begin{array}{r}158,81 \\
2559,30\end{array}$ & $\begin{array}{r}3 \\
2036\end{array}$ & $\begin{array}{r}52,94 \\
1,11\end{array}$ & 47,69 & 0,01 \\
\hline 12 & Besit van vaste eiendom & $\begin{array}{l}\text { Tussen groepe } \\
\text { Binne groepe }\end{array}$ & $\begin{array}{r}54,53 \\
3194,69\end{array}$ & $\begin{array}{r}3 \\
2036\end{array}$ & $\begin{array}{r}18,18 \\
1,57\end{array}$ & 11,58 & 0,01 \\
\hline 13 & Besit van telefoon by woonadres & $\begin{array}{l}\text { Tussen groepe } \\
\text { Binne groepe }\end{array}$ & $\begin{array}{r}11,53 \\
3700,68\end{array}$ & $\begin{array}{r}3 \\
2036\end{array}$ & $\begin{array}{l}3,84 \\
1,82\end{array}$ & 2,11 & Onbeduidend \\
\hline 14 & Ouderdom van kliënt & $\begin{array}{l}\text { Tussen groepe } \\
\text { Binne groepe }\end{array}$ & $\begin{array}{r}53,14 \\
2042,55\end{array}$ & $\begin{array}{r}3 \\
2036\end{array}$ & $\begin{array}{r}17,71 \\
1,00\end{array}$ & 17,71 & 0,01 \\
\hline 15 & Afbetalingstermyn & $\begin{array}{l}\text { Tussen groepe } \\
\text { Binne groepe }\end{array}$ & $\begin{array}{r}98,58 \\
2042,35\end{array}$ & $\begin{array}{r}3 \\
2036\end{array}$ & $\begin{array}{r}32,85 \\
1,00\end{array}$ & 32,85 & 0,01 \\
\hline 16 & Vonnisse teen kredietrekord & $\begin{array}{l}\text { Tussen groepe } \\
\text { Binne groepe }\end{array}$ & $\begin{array}{r}5,25 \\
401,11\end{array}$ & $\begin{array}{r}3 \\
2036\end{array}$ & $\begin{array}{l}1,75 \\
0,20\end{array}$ & 8,75 & 0,01 \\
\hline 17 & Geslag & $\begin{array}{l}\text { Tussen groepe } \\
\text { Binne groepe }\end{array}$ & $\begin{array}{r}218,17 \\
3570,06\end{array}$ & $\begin{array}{r}3 \\
2036\end{array}$ & $\begin{array}{r}72,72 \\
1,75\end{array}$ & 41,55 & 0,01 \\
\hline 18 & Tydperk werksaam by vorige werkgewer & $\begin{array}{l}\text { Tussen groepe } \\
\text { Binne groepe }\end{array}$ & $\begin{array}{r}78,03 \\
1909,91\end{array}$ & $\begin{array}{r}3 \\
2036\end{array}$ & $\begin{array}{r}26,01 \\
0,94\end{array}$ & 27,67 & 0,01 \\
\hline 19 & Gebied woonagtig & $\begin{array}{l}\text { Tussen groepe } \\
\text { Binne groepe }\end{array}$ & $\begin{array}{r}174,12 \\
3338,61\end{array}$ & $\begin{array}{r}3 \\
2036\end{array}$ & $\begin{array}{r}58,04 \\
1,64\end{array}$ & 35,39 & 0,01 \\
\hline 20 & Totale uitgawes van kliënt & $\begin{array}{l}\text { Tussen groepe } \\
\text { Binne groepe }\end{array}$ & $\begin{array}{r}19,90 \\
1842,63\end{array}$ & $\begin{array}{r}3 \\
2036\end{array}$ & $\begin{array}{l}6,63 \\
0,91\end{array}$ & 7,29 & 0,01 \\
\hline 21 & Tydperk werksaam by huidige werkgewer & $\begin{array}{l}\text { Tussen groepe } \\
\text { Binne groepe }\end{array}$ & $\begin{array}{r}69,87 \\
1313,87\end{array}$ & $\begin{array}{r}3 \\
2036\end{array}$ & $\begin{array}{r}23,29 \\
0,65\end{array}$ & 35,83 & 0,01 \\
\hline 22 & Taal & $\begin{array}{l}\text { Tussen groepe } \\
\text { Binne groepe }\end{array}$ & $\begin{array}{r}17,35 \\
1535,42\end{array}$ & $\begin{array}{r}3 \\
2036\end{array}$ & $\begin{array}{l}5,78 \\
0,75\end{array}$ & 7,71 & 0,01 \\
\hline
\end{tabular}


heid van lewens- en/of uitkeerversekering (nr. 2) en besit van telefoon by woonadres (nr. 13), is die verskille onbeduidend. Die grootste verskille tussen rassegroepe volgens die persepsie van bestuurders, kom by ouderdom van artikel $(F$-waarde $=$ $55,61)$, afbetalingstussenposes ( $F$-waarde $=50,46)$ en bestaande of nuwe kliënt $(F$-waarde $=47,69)$ voor. Die nulhipotese (hipotese 1) word dus ten opsigte van 20 keuringskriteria verwerp en die alternatiewe hipotese aanvaar.

Waar presies hierdie verskille is, is met behulp van Scheffé se post-hoc-vergelykingstoets opgespoor. Die vergelykings wat met behulp van Scheffé se toets as beduidend bevind is, word in Tabel 6 aangetoon. Volgens Tabel $6 \mathrm{kan}$ afgelei word dat die grootste verskille tussen kleurlinge en blankes (by $82 \%$ van die keuringskriteria); blankes en swartes (by $82 \%$ van die keuringskriteria) en Indiërs en blankes (ook 82\%) voorkom. Die kleinste getal verskille tussen rassegroepe, kom tussen kleurlinge en Indiërs (14\%) voor. Ook tussen kleurlinge en swartes is die aantal verskille ten opsigte van die 20 keuringskriteria betreklik min, naamlik 10 uit $20(50 \%)$.

Kendall se koëffisiënt van konkordansie, $W$, tussen die relatiewe belangrikheid wat bestuurders aan die keuringskriteria met betrekking tot die verskillende rassegroepe heg, is 0,97 . Hierdie koëffisiënt is beduidend op die 0,01-vlak. In die lig hiervan bestaan daar 'n hoë mate van ooreenstemming tussen die rassegroepe wat betref bestuurderspersepsie van die relatiewe belangrikheid van verskeie keuringskriteria. Die nulhipotese (hipotese 2) word dus verwerp en die alternatiewe hipotese aanvaar.

In Tabel 7 word die gemiddeldes $(\bar{X})$ en standaardafwykings $(S)$ van keuringskriteria ten opsigte van die bestuurderssteekproef vir die onderskeie rassegroepe afsonderlik en gesamentlik aangebied. Uit Tabel 7 blyk dit dat vonnisse teen kredietrekord (nr. 16) ten opsigte van alle groepe deur bestuur as die belangrikste keuringskriterium ge-ag is, gevolg deur bruto inkomste (nr. 1) en kredietverwysings (nr. 9) onderskeidelik tweede en derde belangrikste. Met betrekking tot alle groepe, is taal (nr.
22) relatief as die onbelangrikste kriterium beskou. Die res van die tabel spreek vanself en word nie verder bespreek nie.

\section{Bespreking, Gevolgtrekkings en Aanbevelings}

Die doelstellings van hierdie ondersoek was om:

- Die relatiewe belangrikheid van verskeie keuringskriteria (soos waargeneem vanuit die oogpunt van bankbestuurders) in verbruikersbankwese te bepaal; en

- die relatiewe belangrikheid van die keuringskriteria (soos waargeneem vanuit die oogpunt van bankbestuurders) by die verskillende rassegroepe te vergelyk.

Dit is bevind dat beduidende verskille op die 0,01-vlak ten opsigte van 20 uit die 22 keuringskriteria, met betrekking tot die verskillende rassegroepe bestaan. Hierdie bevinding rym met Jones (1968) se bevinding dat daar verskille tussen laeen hoë-inkomste-verbruikers bestaan, ten opsigte van kredietevaluering. Hierdie bevinding is egter nie in ooreenstemming met dié van Tabor \& Bowers (1977) en Sexton, jr. (1977) nie. Hulle kon geen beduidende verskille met betrekking tot hoë- en lae-inkomstegroepe vind nie. Geen plaaslike literatuur, waar die relatiewe belangrikheid van keuringskriteria (soos waargeneem deur bestuur) ten opsigte van die onderskeie rassegroepe, nagevors is, kon opgespoor word nie.

'n Beduidende korrelasie van 0,97 op die 0,001-vlak is gevind, wat beteken dat daar 'n hoë mate van ooreensternming bestaan tussen die onderskeie rassegroepe, wat betref bestuurderspersepsie van die relatiewe belangrikheid van verskeie keuringskriteria. Indien aanvaar word dat die persepsie van 'n individu (' $n$ bestuurder) tot uiting kom in sy gedrag (Shiffman \& Kanuk, 1983; Baron, 1983 en Dunham, 1984, kan gesuggereer word dat die gedrag van bestuur (by die keuringsproses) met betrekking tot die onderskeie rassegroepe korreleer.

Daar word aanbeveel dat:

- 'n Soortgelyke ondersoek met korporatiewe klïnte in plaas van verbruikers as kliënte uitgevoer word;

Tabel 6 Scheffé se toets met betrekking tot die rassegroepe ten opsigte van die keuringskriteria

\begin{tabular}{|c|c|c|c|c|c|c|c|}
\hline \multirow[b]{2}{*}{$\begin{array}{l}\text { Kriterium } \\
\text { nommer }\end{array}$} & \multirow[b]{2}{*}{$\begin{array}{l}\text { Beskrywing } \\
\text { van keuringskriteria }\end{array}$} & \multicolumn{6}{|c|}{ Vergelyking } \\
\hline & & $\begin{array}{c}\text { Kleurlinge } \\
\text { vs } \\
\text { Indiërs } \\
(F)\end{array}$ & $\begin{array}{c}\text { Kleurlinge } \\
\text { vs } \\
\text { blankes } \\
(F)\end{array}$ & $\begin{array}{c}\text { Kleurlinge } \\
\text { vs } \\
\text { swartes } \\
(F)\end{array}$ & $\begin{array}{l}\text { Indiërs } \\
\text { vs } \\
\text { blankes } \\
(F)\end{array}$ & $\begin{array}{l}\text { Indiërs } \\
\text { vs } \\
\text { swartes } \\
\text { (F) }\end{array}$ & $\begin{array}{c}\text { Blankes } \\
\text { vs } \\
\text { swartes } \\
\text { (F) }\end{array}$ \\
\hline 1 & Bruto inkomste van kliënt & 1,80 & $48,05^{n}$ & 1,25 & $31,25^{2}$ & $6,05^{a}$ & $64,80^{\mathrm{n}}$ \\
\hline 3 & Huwelikstatus & 1,35 & $2,82^{b}$ & $14,02^{\mathrm{a}}$ & 0,27 & $6,67^{2}$ & $4,27^{\star}$ \\
\hline 4 & Aantal afhanklikes & $5,40^{\mathrm{a}}$ & $28,02^{2}$ & 2,02 & $8,82^{n}$ & 0,82 & $15,00^{\circ}$ \\
\hline 5 & Tydperk woonagtig by huidige adres & 0,83 & $83,33^{2}$ & 0,01 & $67,50^{\circ}$ & 0,83 & $83,33^{\star}$ \\
\hline 6 & Beroep & 1,23 & $25,60^{2}$ & 2,03 & $15,63^{\star}$ & $5,63^{n}$ & $42,03^{*}$ \\
\hline 7 & Ouderdom van artikel & 1,20 & $93,63^{a}$ & $4,03^{2}$ & $73,63^{n}$ & $9,63^{2}$ & $136,53^{\mathrm{a}}$ \\
\hline 8 & Afbetalingstussenposes & 0,90 & $102,40^{\mathrm{a}}$ & 1,60 & $84,10^{2}$ & $4,90^{2}$ & $129,60^{2}$ \\
\hline 9 & Kredietverwysings & 0,13 & $34,13^{a}$ & 1,63 & $38,53^{2}$ & 0,83 & $50,70^{a}$ \\
\hline 10 & Besit van bankrekening & $5,78^{a}$ & $18,00^{2}$ & $9,68^{2}$ & $3,38^{b}$ & 0,50 & 1,28 \\
\hline 11 & Bestaande of nuwe kliënt & 0,23 & $87,03^{2}$ & 2,50 & $96,10^{2}$ & 1,23 & $119,03^{2}$ \\
\hline 12 & Besit van vaste eiendom & $3,75^{b}$ & 1,35 & $15,00^{2}$ & $9,60^{\circ}$ & $33,75^{\mathrm{a}}$ & 0,15 \\
\hline 14 & Ouderdom van kliënt & 0,23 & $32,40^{2}$ & 1,60 & $27,23^{\star}$ & $3,03^{b}$ & $48,40^{a}$ \\
\hline 15 & Afbetalingstermyn & 0,40 & $50,63^{2}$ & $4,23^{2}$ & $42,05^{a}$ & $8,10^{2}$ & $87,03^{2}$ \\
\hline 16 & Vonisse teen kredietrekord & 0,10 & $14,40^{2}$ & 0,10 & $16,90^{2}$ & 0,40 & $12,10^{2}$ \\
\hline 17 & Geslag & 1,16 & $58,51^{\star}$ & $10,41^{a}$ & $43,21^{\star}$ & $18,51^{\star}$ & $118,30^{2}$ \\
\hline 18 & Tydperk werksaam by vorige werkgewer & 0,40 & $40,00^{2}$ & $3,60^{b}$ & $32,40^{2}$ & $6,40^{\mathrm{a}}$ & $67,60^{2}$ \\
\hline 19 & Gebied woonagtig & 0,60 & $50,42^{2}$ & $11,27^{\star}$ & $40,02^{*}$ & $17,07^{\mathrm{a}}$ & $109,35^{\star}$ \\
\hline 20 & Totale uitgawes & 0,23 & $13,23^{\mathrm{a}}$ & 0,01 & $11,03^{n}$ & 0,10 & $13,23^{2}$ \\
\hline 21 & Tydperk werksaam by huidige werkgewer & 0,03 & $48,13^{\mathrm{a}}$ & $4,03^{\mathrm{a}}$ & $43,20^{\mathrm{a}}$ & $4,80^{\mathrm{a}}$ & $76,80^{2}$ \\
\hline 22 & Taal & 0,13 & 0,53 & $13,33^{2}$ & 1,20 & $10,80^{2}$ & $19,20^{\circ}$ \\
\hline
\end{tabular}

Beduidend op die 0,01-vlak; 'Beduidend op die 0,05-vlak 
Tabel 7 Gemiddeldes $(\bar{X})$ en standaardafwykings (S) van keuringskriteria ten opsigte van bestuurderssteekproef vir rassegroepe afsonderlik en gesamentlik

\begin{tabular}{|c|c|c|c|c|c|c|c|c|c|c|c|}
\hline \multirow{2}{*}{$\begin{array}{l}\text { Keurings- } \\
\text { kriterium } \\
\text { nommer }\end{array}$} & \multirow{2}{*}{$\begin{array}{l}\text { Beskrywing van } \\
\text { keuringskriterium }\end{array}$} & \multicolumn{2}{|c|}{ Kleurlinge } & \multicolumn{2}{|c|}{ Indiërs } & \multicolumn{2}{|c|}{ Blankes } & \multicolumn{2}{|c|}{ Swartes } & \multicolumn{2}{|c|}{ Alle groepe } \\
\hline & & 8 & $S$ & $\not$ & $S$ & $\bar{X}$ & $S$ & $\bar{X}$ & $S$ & $\bar{X}$ & $s$ \\
\hline 1 & $\begin{array}{l}\text { Bruto inkomste van } \\
\text { kliënt }\end{array}$ & 4,65294 & 0,65679 & 4,59020 & 0,71656 & 4,33725 & 0,82922 & 4,70356 & 0,71412 & 4,57073 & 0,74478 \\
\hline 2 & $\begin{array}{l}\text { Aanwesigheid van } \\
\text { lewens- en/of uitkeer- } \\
\text { versekering }\end{array}$ & 3,09804 & 1,30820 & 3,07647 & 1,30438 & 3,03529 & 1,13989 & 2,96640 & 1,44498 & 3,04420 & 1,30356 \\
\hline 3 & ikstatus & 2,90196 & 1,22442 & 2,81373 & 1,21169 & 2,76667 & 1,15518 & 2,61462 & 1,33487 & 2,77456 & 1,23653 \\
\hline 4 & Aantal afhanklikes & 3,57059 & 1,20164 & 3,39804 & 1,20591 & 3,16471 & 1,13019 & 3,46245 & 1,34517 & 3,39882 & 1,23108 \\
\hline 5 & $\begin{array}{l}\text { Tydperk woonagtig by } \\
\text { huidige adres }\end{array}$ & 4,245 & 0,88244 & & & 3,75098 & 0,98851 & 4,24901 & 0,99765 & 4,11149 & 0,96313 \\
\hline 6 & Beroep & 4,123 & 0,96 & 4,05294 & 0,99 & 3,80 & 0,9 & 4,20553 & 1,04609 & 4,04568 & 0,99699 \\
\hline 7 & dom van artikel & 4,398 & & 4,33529 & 0,8 & 87255 & 0,97 & 4,50988 & 0,77389 & 4,27849 & 0,87866 \\
\hline 8 & nposes & 4,25490 & & 4,19020 & 1,0 & 3,61373 & 1,090 & 4,33399 & 1,01 & 4,09 & 1,08271 \\
\hline 9 & & 4,45294 & & 4,47255 & 0,86983 & 4,12549 & 0,94 & 4,52372 & 0,853 & 4,39342 & 0,90042 \\
\hline 10 & bankrekening & 3,63529 & 1,10025 & 3,66863 & 1,07389 & 3,53725 & 1,00372 & 3,62451 & 1,20120 & 3,61640 & 1,09711 \\
\hline 11 & $\begin{array}{l}\text { Bestaande of nuwe } \\
\text { kliënt }\end{array}$ & 4,05490 & 1,03235 & 4,07843 & 1,02317 & 3,45882 & 1,10423 & 4,14625 & 1,05978 & 3,93418 & 1,09031 \\
\hline 12 & $\begin{array}{l}\text { Besit van vaste } \\
\text { eiendom }\end{array}$ & 3,83137 & 1,21831 & 3,98235 & 1,15994 & 3,73922 & 1,09859 & 3,53162 & 1,48790 & 3,77161 & 1,25923 \\
\hline 13 & $\begin{array}{l}\text { Besit van telefoon } \\
\text { by woonadres }\end{array}$ & & & 3,04510 & & (a) & & 2,86166 & & & 1,34926 \\
\hline 14 & Ouderdom van kliënt & 3,68431 & 0,98133 & 3,65294 & & 3,31 & 0,99 & 3,73518 & 1,04788 & 3,59774 & 1,02104 \\
\hline 15 & Afbetalingstermyn & 3,81569 & 1,06809 & 3,76863 & 1,06995 & 3,36471 & 1,03586 & 3,95455 & 1,10261 & 3,72544 & 1,09084 \\
\hline 16 & $\begin{array}{l}\text { Vonnisse teen krediet- } \\
\text { rekord }\end{array}$ & & & & & & & 4,86364 & & 4,84037 & 0,44728 \\
\hline 17 & Geslag & 3,10784 & 1,35394 & 3,02353 & 1,36164 & 2,47255 & 1,12055 & 3,37549 & 1,44377 & 2,99411 & 1,36433 \\
\hline 18 & $\begin{array}{l}\text { Tydperk werksaam by } \\
\text { vorige werkgewer }\end{array}$ & & & & & & & 4,11858 & & 3,92043 & 0,98518 \\
\hline 19 & Gebied woonagtig & 3,22745 & 1,27205 & 3,17451 & 1,26729 & 2,68431 & 1,18618 & 3,49012 & 1,38052 & 3,14342 & 1,30997 \\
\hline 20 & Totale uitgawes & 4,32745 & 0,92373 & 4,30196 & 0,93133 & 4,10392 & 0,98664 & 4,33202 & 0,96495 & 4,26621 & 0,9559 \\
\hline 21 & $\begin{array}{l}\text { Tydperk werksaam by } \\
\text { huidige werkgewer }\end{array}$ & & & 4,38431 & & & & 4,50000 & & & 0,82627 \\
\hline 22 & Taal & 1,36275 & 0,80261 & 1,38235 & 0,84384 & 1,32157 & 0,74862 & 1,55731 & 1,05571 & 1,40570 & 0,87411 \\
\hline
\end{tabular}

- 'n soortgelyke ondersoek uitgevoer word ten opsigte van die verskillende rassegroepe waarin die persepsie van handelsbankbestuurders met betrekking tot byvoorbeeld tjekrekening-voorskotte en lenings nagevors word;

- Suid-Afrikaanse bankinstellings wat van kredietrisikovoorspellingsmodelle gebruik maak, wat moontlik gebaseer is op toestande en praktyke buite Suid-Afrika, hulle vergewis van die eiesoortige situasie in Suid-Afrika; en

- dit raadsaam mag wees om te probeer vasstel hoe die psigografiese profiel (byvoorbeeld lewensstyl, selfbeeld, sosiale klas en persoonlikheid) van die keuringsamptenaar die kredietevalueringsproses beïnvloed. Lig op hierdie onderwerp mag daartoe bydra dat die 'ideale' keuringsamptenaar moontlik geidentifiseer word.

\section{Summary}

The study has the following objectives:

- To determine the relative importance of various evaluation criteria (as observed by bank managers) in considering the granting of credit to individuals in consumer banking.

- To compare the relative importance of evaluation criteria (as observed by bank managers) with regard to the various race groups (coloureds, Indians, whites and blacks) of the Republic of South Africa.

Two hypotheses related to the above objectives are tested, namely:

\section{Hypothesis 1}

- $\mathrm{H}_{0}$ : There is no difference regarding the relative importance of various evaluation criteria (as observed by bank managers) in considering the granting of credit to indivi- duals in consumer banking with respect to various race groups;

- $\mathrm{H}_{\mathrm{i}}$ : There is a difference regarding the relative importance of various evaluation criteria (as observed by bank managers) in considering the granting of credit to individuals in consumer banking with respect to various race groups.

\section{Hypothesis 2}

- $\mathrm{H}_{0}$ : There is no correlation between the relative importance of evaluation criteria (as observed by bank managers) with regard to the various race groups.

- $\mathrm{H}_{\mathrm{i}}$ : There is a correlation between the relative importance of evaluation criteria (as observed by bank managers) with regard to the various race groups.

The investigation is limited to commercial and general banks, since they are the largest 'suppliers' of consumer credit in the form of instalment credit (hire purchase) and leasing transactions. The investigation includes coloureds, Indians, whites and blacks. The sample consists of 510 managers from the consumer divisions of six general and commercial bank groups.

Hypothesis 1 is tested by means of analysis of variance. If $F$ is significant, the appropriate prosedure of Sheffé is used.

Hypothesis 2 is tested with Kendall's coefficient of concordance $(W)$.

The following conclusions are drawn:

- Significant differences exist regarding the relative importance of the evaluation criteria (according to the perception of bank managers) with respect to the various race groups (Hypothesis 1); 
- correlation between race groups concerning managers' perception of the relative importance of various evaluation criteria is high (Hypothesis 1); and

- various recommendations for future related research are made.

\section{Verwysings}

Baron, R.A. 1983. Behavior in Organizations. Boston, London: Allyn and Bacon, Inc.

Beckman, T.N. \& Bartels, R. 1955. Credits and Collections in Theory and Practice. 6th Edition. McGraw-Hill Book Company, Inc.

Boggess, W.P. 1967. Screen-test your credit risks. Harv. Bus Rev., vol 45, 113-112.

Cole, R.H. 1982. Consumer and commercial Credit Management. Homewood, Illinois: Richard D Irvin, Inc.

Dickson, G.C.A. 1981. A comparison of attitudes towards risk among business managers. J. Occup. Psychol., vol 54, $157-164$.

Dunham, R.B. 1984. Organizational Behavior: People and Processes in Management. Homewood, Illinois: Richard D Irwin, Ine.

Eisenbeis, R.A. 1980. Selection and Disclosure of Reasons for Adverse Action in Credit-Granting Systems. Fed. Reserve Bull., vol 66, 727-735.

Grablowsky, B.J. \& Talley, W.K. 1981. Probit and discriminant functions for classifying credit applications: a comparison. $J$. Econ. Bus., vol 33, 254-261.

Grayson, C.J. 1960. Decisions under uncertainty: Drilling decisions by oil and gas operators. Div. Res. Harv. Bus. Sch., Boston.

Handa, J. 1977. Risk, probabilities and a new theory of cardinal utility. J. Pol. Econ., 97-122.

Jones, M.G. 1968. Credit and low-income consumers. Ind. Banker, May, 8-14.

Karmarker, U.S. 1978. Subjectively weighted utility: A description extension of the expected utility model. Organ. Behav. Hum. Performance, $61-72$.
Pinches, G.E. \& Mingo, K.A. 1973. A Multivariate Analysis of Industrial Bond Ratings. J. Finance, vol 28, 1-18.

Rothenberg, D. 1980. Predicting the Status of your loan ... Three years from now. J. Commer. Bank Lending, 28-41.

Schiffman, L.G. \& Kanuk, L.L. 1983. Consumer behaviour. 2nd Edition. Englewood Cliffs, New Jersey: Prentice Hall Inc.

Senger, J. 1971. Managers' Perceptions of Subordinates' Competence as a Function of Personal Value Orientations. Acad. Mgmt. J., 415-423.

Sexton, jun., D.E. 1977. Determining Good and Bad Credit Risks among High- and Low-Income Families. J. Bus., vol S0, $236-239$.

Sinkey, jun., J.F. 1983. Commercial Bank Financial Management. New York: MacMillan Publishing Co, Inc.

Spetzler, C.S. 1968. Development of a corporate risk policy for capital investment decisions. IEEE Trans. Syst., Sci. Cybern., SSC-279-300.

Stanhouse, B. \& Sherman, L. 1979. A note on information in loan evaluation process. J. Finance, vol 34, 1263-1269.

Suid-Afrikaanse Reserwebank, 1980: Kwartaalblad, Maar 1980, Nr 143.

Suid-Afrikaanse Reserwebank, 1985: Kwartaalblad, Maart 1985, $\mathrm{Nr} 155$.

Tabor, J.S. \& Bowers, J.S. 1977. Factors Determining Credit Worthiness of Low Income Consumers. J. Consum. Affairs, vol $11,43-51$.

Van Rensburg, W.P.J. 1983. Die voorspelling van kredietrisiko met behulp van Biografiese veranderlikes. Ongepubliseerde M.Comm-verhandeling, Universiteit van Suid-Afrika, Pretoria, Maart 1983.

Wantland, C.A. 1977. How a Banker Evaluates a Credit Risk. Credit Finan. Mgmt., vol 77, 16-17.

Wingington, J.C. 1980. A note on the comparison of logit and discriminant models of consumer credit behaviour. J. Finan. Quan. Anal., vol 15, 757-766.

Zimmer, I. 1981. A comparison of the Prediction Accuracy of Loan Officers and their Linear-Additive Models. Organ. Behav. Hum. Performance, vol 27, 69-74. 